\title{
Effect of gamma radiation on the lipid profiles of soybean, peanut and sesame seed oils
}

\author{
By A.M.R. Afify, M.M. Rashed, A.M. Ebtesam and H.S. El-Beltagi ${ }^{\bowtie}$
}

\author{
Biochemistry Dept., Faculty of Agriculture, Cairo University, P. Box 12613, Gamma st, Giza, Cairo- Egypt \\ Corresponding author: Ibltg@yahoo.com
}

\section{RESUMEN}

Efecto de la radiación gamma sobre el perfil lipídico de los aceites de semillas de soja, cacahuete y sésamo

Semillas de soja, cacahuete y de sésamo se expusieron a diferentes dosis de radiación gamma $(0,0,0,5,1,0,2,0,3,0,5,0$ y 7,5 kGy). Se determinaron los perfiles de ácidos grasos y el insaponificable de los aceites mediante cromatografía de gases y espectrometría de masas. Los resultados demostraron que las relaciones de ácidos insaturados a ácidos grasos totales saturados (TU/TS) e hidrocarburos totales a esteroles (TH/TSt) se alteró significativamente tras la irradiación. Estos cambios se observaron claramente en el aceite extraído de las semillas de sésamo irradiados, en comparación con los aceites de soja y cacahuetes irradiados. El mayor cambio en la composición de ácidos grasos fue la disminución de la cantidad de ácidos grasos insaturados (C18:1 y C18:2) en todos los casos. En contraste, los niveles de las fracciones de esteroles como colesterol, campesterol, estigmasterol y $\beta$-sitosterol de las semillas irradiadas fueron en general más bajo que el de las semillas sin irradiados.

PALABRAS CLAVE: Ácidos grasos - Esteroles - Hidrocarburos - Irradiación Gamma - Semillas oleaginosas.

\section{SUMMARY}

Effect of gamma radiation on the lipid profiles of soybean, peanut and sesame seed oils

Seeds of soybean, peanut, and sesame were exposed to various doses of gamma irradiation $(0.0,0.5,1.0,2.0,3.0$, 5.0 and $7.5 \mathrm{kGy}$ ). Fatty acid and unsaponifiable profiles of the extracted oils were separated by gas chromatography mass spectroscopy. The results demonstrated that the ratios of unsaturated to saturated total fatty acids (TU/TS) and total hydrocarbons to sterols (TH/TSt) were significantly altered upon irradiation. These changes were clearly observed in the oil extracted from irradiated sesame seeds compared with the oils from irradiated peanuts and soybean. The major change in fatty acid composition was the decrease in the quantity of unsaturated fatty acids (C18:1 and C18:2) in all cases. In contrast, the sterol fractions such as cholesterol, campesterol, stigmasterol and $\beta$-sitosterol levels of irradiated seeds were generally lower than that of the un-irradiated seeds.

KEY-WORDS: Fatty acids - Gamma irradiation Hydrocarbon - Oil seeds - Sterol.

\section{INTRODUCTION}

Soybean oil is commonly called "vegetable oil" and considered the world's largest oilseed crop, with about 13 million tons of oil produced each year (Patterson, 1989). Soybeans are in high demand due to their high protein and oil contents (Erickson et al., 1980). They contain roughly from 19 to $25 \%$ oil, of which triglycerides are the major component. Soybean oil is characterized by relatively large amounts of the polyunsaturated fatty acids (PUFA), i.e., $~ 55 \%$ linoleic acid and $\sim 8 \% \alpha$-linolenic acid with few oleic acids of the total fatty acids (Messina, 1997).

Peanuts are of great importance in foods worldwide. Peanut oil contents in 17 cultivars ranged from 45.7 to $51.8 \%$ (Nelson et al., 2000). It is a pale yellow, non-drying oil containing large quantities of arachidonic, oleic, linoleic, palmitic and stearic acids. There are also small concentrations of behenic and lignoceric acids, about $1.5 \%$ each (Oyinlola et al., 2004). Sesame (Sesamum indicum L.) is a very ancient oilseed crop and one of the earliest domesticated oil crops in the world. It acquired importance as a source of cheap vegetable oil and proteins, a good source of natural antioxidants (sesamin and sesamolin) dñp0pwhich are unique for sesame and present in the oil (Ashri, 2007). The total lipid fraction of 28 sesame cultivars ranged from 46.5 to $60.0 \%$. The fatty acid composition in sesame oil consist mainly of linoleic and oleic acids with small amounts of saturated fatty acids. However, the brown seed variety was higher in oleic acid and lower in linoleic, palmitic and stearic acids (Mohamed and Awatif, 1998). In the last decade, $\gamma$-irradiation has drawn attention as a new and rapid method for improving the qualitative and quantitative characteristics of many crops. Gamma irradiation has been widely applied in medicine and biology in terms of biological effects induced by a counter intuitive switch-over from low doses stimulation to high-doses inhibition (Charbaji and Nabulsi, 1999, Afify et al., 2012). Irradiation processing is mainly employed to extend the shelf-life and secure the quality of foods by decreasing the microbial load which causes the spoilage of food. It is an appropriate approach for the disinfection of cereals, spices, dried fruits and nuts (El-Beltagi 2001, Cetinkaya et al., 2006). The importance of the irradiation process is not only due to its efficiency for the destruction of undesired microorganisms and extension of shelf-life, but also for its effects 
on the physico-chemical, nutritive, and biological characteristics of foods (Dogbevi et al., 1999, Golge and Ova, 2008). Gamma rays are known to influence plant growth and development by inducing cytological, genetic, biochemical, physiological and morphogenetic changes in cells and tissue (Gunckel and Sparrow, 1961). Also, it has been shown to enhance the production of reactive oxygen species (ROS) in a variety of cells resulting from oxidative stress (Repine et al., 1981; von Sonntag, 1987, Xienia et al., 2000). Recent evidence suggests that reactive oxygen species play an important role in the action of ionizing radiation (Ewing and Jones, 1987, Alaoui et al., 1992, Aly and El-Beltagi 2010; Afify et al., 2011a). ROS are the byproducts of many degenerative reactions in crop plants, which will affect the regular metabolism by damaging the cellular components (Foyer and Noctor, 2002). Extensive study on oxidative stress has demonstrated that exposure of plants to adverse environmental conditions induces the overproduction of reactive oxygen species (ROS), such as superoxide radical $\left(\mathrm{O}_{2}^{-}\right)$, $\mathrm{H}_{2} \mathrm{O}_{2}$ and hydroxyl radical $\left(\mathrm{HO}^{\circ}\right)$ in plant cells (Wise and Naylor, 1987, El-Beltagi, 2011). In addition, ROS are highly reactive to membrane lipids, protein and DNA (Afify et al., 2011b, El-Beltagi et al., 2011a,b, El-Beltagi et al., 2012). Irradiation has been shown to cause some physicochemical changes such as reducing viscosity, increasing water solubility, acidity, etc. in starchy foods (Lee et al., 2003, Yook et al., 2004). The low radiation dose used could have produced its long-term effects in part by means of the stimulation of lipid degradation, possibly mediated through the action of free radicals that are known to be generated after irradiation (Katsaras et al., 1986, Voisine et al., 1991). In plant tissues subjected to different forms of stress, lipids are degraded to generate free fatty acids and diacylglycerols, resulting in an eventual accumulation of $\mathrm{TG}$ as a defense mechanism (Olsson, 1995). In animal cells, the metabolites of polyunsaturated fatty acids including hydroperoxy fatty acids represent an important class of biological mediators which are released as a result of treatment with ionizing radiations (Steel et al., 1988). It is rather important to determine whether ionizing radiation may be involved in the synthesis of oxygenated polyunsaturated fatty acids in foods of plant origin. Polyunsaturated fatty acids are susceptible to oxidation by radical processes. It is well known that free radicals are formed in food by ionizing radiation (Wills, 1980). The general mechanism of the radiolysis of fats was lead to primary ionization, followed by migration of positive charges towards the carboxyl groups and the double bond cleavage at preferential positions near the carbonyl group. The resulting free radicals engage in various reactions leading to the formation of stable radiolytic products, which have been classified as primary, recombination, and secondary products according to the mode of their formation; but in the case of unsaturated fatty acids, the dimerization reaction appear to be of major importance (Nawar, 1978). The irradiation of lipids with $10 \mathrm{kGy}$ reduced the amount of trienoic fatty acids with triple bonds while double bonds were correspondingly increased; therefore polyenoic acids were the main source of oxidative deterioration problems in fats (Sokolov, 1965). Ionizing radiation caused the oxidation of lipids, even in the absence of oxygen through decarboxylated and unsaturated fatty acids polymerized, but in the presence of oxygen, and hydroperoxides and carbonyls were formed (Lawrie, 1974). Gamma radiation treatments caused a loss of tocopherols in the peanut oil extracted (Bhatti et al., 2010). Since Nawar's group (Champagne and Nawar, 1969; Dubravcic and Nawar, 1969) reported that some hydrocarbons are exclusively produced by the $\gamma$-radiation of lipids and lipid-containing foods, hydrocarbons have been extensively studied as markers to detect the irradiation of foods. Two types of hydrocarbons are predominantly produced by the irradiation of fatty acids: a hydrocarbon that has one carbon less than the parent fatty acid $\left(\mathrm{C}_{n-1}\right)$ and a hydrocarbon that has two carbons less and an additional double bond at position $1\left(\mathrm{C}_{n-2}, 1\right.$-ene) (Dubravcic and Nawar, 1968; Spiegelberg et al., 1994). The hydrocarbons exclusively detected in irradiated foods have been suggested to be used as markers for identifying post-irradiation of the foods that are fairly high in lipids, such as meats (Hwang, 1999a), eggs (Hwang, 1999b; Hwang et al., 2001), peanuts (Park and Hwang, 1999), soybean (Hwang et al., 2007) and sesame seeds (Choi and Hwang, 1997). Severe heating of peanut oils induced the formation of some hydrocarbons; however, the pattern of hydrocarbon production by the heating was totally different from irradiation (Lesgards et al., 1993).

The main purpose of this investigation was to study the changes in lipid profile fractions; fatty acids, hydrocarbons and sterols of three oil seeds (soybean, peanut and sesame) as a result of gamma irradiation with a range from 0.5 to $7.5 \mathrm{kGy}$.

\section{MATERIAL AND METHODS}

\subsection{Materials}

Soybean seeds (Glycin Max L., Var. Clark), Peanut seeds (Arachis Hypogaea L., Var. Giza5) and Sesame seeds (Sesame indicum L., Var. Giza 32) were obtained from the Food Legumes Research Department, Field Crops Research Institute, Agricultural Research Center, Giza, Egypt.

\subsection{Irradiation treatments}

Irradiation treatments were performed using the Cobalt 60 source from unit Gamma Chamber 4000, at the National Center for Research and Radiation Technology, Naser City, Cairo at a dose rate of $4.166 \mathrm{rad} / \mathrm{second}$. 


\subsection{Chemical analysis}

\subsubsection{Lipid Extraction}

The seed oil content was determined using the Soxhlet extraction according to the official method (AOAC, 2000). From each cultivar, 50 $\mathrm{g}$ of seeds were ground and then extracted with petroleum ether in a Soxhlet apparatus for $6 \mathrm{~h}$. After extraction, the samples were ground again, but more finely, and extracted for $6 \mathrm{~h}$ (second extraction). Petroleum ether was evaporated under reduced pressure using a rotavapor. Lipid content was expressed as $\mathrm{g} 100 \mathrm{~g}^{-1}$ of seed fresh weight.

\subsubsection{Separation of fatty acids and unsaponifiables from lipid samples}

Lipid material was saponified with methanolic $\mathrm{KOH}$ $(40 \%, w / v)$ for $24 \mathrm{~h}$ at room temperature according to Ahmed et al. (1986). The unsaponifiables were extracted three times with ether. The aqueous layer was acidified with $\mathrm{HCl}(1: 1, v / v)$ and the liberated fatty acids were extracted three times with ether. The combined extracts of unsaponifiables and fatty acids were washed several times with distilled water and then dried over anhydrous sodium sulfate.

\subsubsection{Methylation of lipid materials}

The standard and the sample fatty acids were converted to methyl esters using the ethereal solution of diazomethane according to Vogal (1975).

\subsubsection{Determination of fatty acid composition by GC-MS}

The fatty acid methyl esters were determined by GC-MS using a Trace GC Model 2000 series produced by Thermo equipped with a Selective Detector Mass Spectroscopy Model SSQ 7000 produced by Finnigan. This equipment was interfaced via HP chemstation version A 02.12 software (HewelwettPackard. Avondale, PA). The gas chromatography was equipped with a DB-23 (J \& W 122-2362) $25 \mu$ capillary column, $60 \mathrm{~m} \times 0.25 \mathrm{~mm}$ ID, $0.15 \mu \mathrm{m}$. The operating conditions for gas chromatography were as follows: injector temperature $250^{\circ} \mathrm{C}$, carrier gas: helium at $30 \mathrm{~cm} \mathrm{sec}{ }^{-1}$, measured at $150^{\circ} \mathrm{C}$, oven temperature $50^{\circ} \mathrm{C}$ for $4 \mathrm{~min}, 150^{\circ} \mathrm{C}$ for $4 \mathrm{~min}$ and held at $250^{\circ} \mathrm{C}$ until the chromatogram was completed. The detector temperature was $280^{\circ} \mathrm{C}$. Mass spectroscopy operating parameters were electron ionization at $70 \mathrm{ev}$, accelerating voltage $10 \mathrm{kV}$ and scan $\mathrm{M} / \mathrm{Z}$ range from 50 to 500. (National Institute of Standards and Technology (NIST) library according to Jiang et al. (2006)).

\subsubsection{Determination of unsaponifiable profile by $\mathrm{GC}-\mathrm{MS}$}

The unsaponifiable fractions were collected in ether and taken to dryness under vacuum. The residue was analyzed using the gas chromatograph HP 5890 (Hewlett Packard) equipped with the MS detector (MSD 5970), El, 70 ev and fitted with a capillary column DB-1701 (12 $\mathrm{m} \times 0.18 \mathrm{~mm} \times 0.4$ $\mathrm{mm}$; J\&W Scientific). The column temperature was programmed from 260 to $300^{\circ} \mathrm{C}$ while the injection temperature was set at $280^{\circ} \mathrm{C}$. Helium was the carrier gas at a flow rate of $0.7 \mathrm{~cm}^{3} \mathrm{~min}^{-1}$. The Identification of peaks was based on the retention time of standard substances and MS spectra. Analyses were run in triplicate. Calculations of percent composition of dimethyl hydrocarbons and demethylsterol fractions were based on the peak area.

\subsubsection{Iodine value}

The iodine value of the oil extracted from the seeds was determined according to the method described in AOAC (2000).

\subsubsection{Statistical analysis}

The results were expressed as the mean \pm SD to show variations in a group.

\section{RESULTS AND DISCUSSION}

\subsection{Fatty acid composition of irradiated oil seed}

The gamma irradiation of oil seeds could produce chemical changes in different constants, especially lipids, by catalyzing their reaction with molecular oxygen caused autoxidation or by direct oxidation of the unsaturated site of fatty acids with free radicals. Therefore, both effects could be superimposed.

\subsubsection{Soybean seeds}

The results in Table 1 show the effect of different doses of gamma irradiation on the fatty acid composition of soybean. The data show that the non-irradiated soybean contained C16:0, C18:1, C18:2 and C18:3 which comprised more than $86 \%$ of total fatty acids and reduced to about $83 \%$ in irradiated samples. The $\gamma$-irradiation caused the alteration of the unsaturated and saturated fatty acid composition of soybean which showed an increase in the relative amounts of saturated fatty acids; C14:0, C16:0 and C18:0 and a decrease in the unsaturated fatty acids; C16:1, C18:1,C18:2 and C18:3. The ratio between total unsaturated fatty acids and saturated ones (TU/ TS) was 3.60 for the control soybean oil seed, while it decreased gradually in parallel with the irradiation doses and confirmed with the results of iodine values (Table 1). The present findings agree with previous studies, where it was found that $\gamma$-irradiation had some effects on the physical 
Table 1

Fatty acid composition of soybean irradiated with different doses of gamma rays

\begin{tabular}{|c|c|c|c|c|c|c|c|}
\hline \multirow{2}{*}{ Fatty Acids } & \multicolumn{7}{|c|}{ Irradiation dose (kGy) } \\
\hline & Control 0.0 & 0.5 & 1 & 2 & 3 & 5 & 7.5 \\
\hline Caprilic (8:0) & $0.54 \pm 0.02$ & $0.79 \pm 0.01$ & $0.36 \pm 0.01$ & $0.67 \pm 0.01$ & $0.75 \pm 0.01$ & $0.72 \pm 0.010$ & $0.90 \pm 0.02$ \\
\hline Myristic (14:0) & $2.10 \pm 0.12$ & $2.34 \pm 0.15$ & $2.44 \pm 0.06$ & $2.60 \pm 0.08$ & $3.09 \pm 0.10$ & $3.55 \pm 0.08$ & $3.29 \pm 0.11$ \\
\hline Palmitic (16:0) & $11.24 \pm 0.21$ & $11.78 \pm 0.22$ & $12.16 \pm 0.29$ & $12.86 \pm 0.14$ & $12.92 \pm 0.12$ & $12.97 \pm 0.22$ & $13.24 \pm 0.13$ \\
\hline Stearic (18:0) & $2.20 \pm 0.09$ & $1.99 \pm 0.07$ & $2.00 \pm 0.08$ & $1.89 \pm 0.07$ & $1.18 \pm 0.05$ & $1.86 \pm 0.06$ & $1.59 \pm 0.07$ \\
\hline Oleic (18:1) & $5.49 \pm 0.16$ & $6.29 \pm 0.19$ & $6.91 \pm 0.21$ & $6.89 \pm 0.22$ & $6.84 \pm 0.20$ & $7.05 \pm 0.23$ & $7.50 \pm 0.22$ \\
\hline Linoleic (18:2) & $22.18 \pm 0.32$ & $22.11 \pm 0.34$ & $21.20 \pm 0.41$ & $21.08 \pm 0.37$ & $21.05 \pm 0.31$ & $20.37 \pm 0.34$ & $20.30 \pm 0.42$ \\
\hline Arachidic (20:0) & $46.26 \pm 0.56$ & $45.56 \pm 0.52$ & $45.56 \pm 0.64$ & $45.04 \pm 0.51$ & $45.00 \pm 0.60$ & $44.60 \pm 0.63$ & $43.95 \pm 0.55$ \\
\hline Eicosanoic (20:1) & $7.08 \pm 0.16$ & $6.50 \pm 0.15$ & $6.83 \pm 0.14$ & $6.59 \pm 0.19$ & $6.41 \pm 0.22$ & $6.12 \pm 0.13$ & $6.10 \pm 0.18$ \\
\hline Behenic 22:0 & $2.51 \pm 0.09$ & $2.11 \pm 0.11$ & $2.13 \pm 0.08$ & $2.13 \pm 0.10$ & $2.47 \pm 0.13$ & $2.56 \pm 0.11$ & $2.45 \pm 0.07$ \\
\hline Lignoceric (24:0) & $0.40 \pm 0.06$ & $0.51 \pm 0.08$ & $0.41 \pm 0.05$ & $0.26 \pm 0.02$ & $0.30 \pm 0.04$ & $0.21 \pm 0.03$ & $0.40 \pm 0.07$ \\
\hline $\mathrm{TS}^{\mathrm{a}}$ & $21.89 \pm 0.42$ & $23.32 \pm 0.50$ & $24.00 \pm 0.51$ & $25.15 \pm 0.62$ & $26.06 \pm 0.65$ & $26.84 \pm 0.70$ & $27.76 \pm 0.81$ \\
\hline$T^{b}$ & $78.11 \pm 3.64$ & $76.68 \pm 3.38$ & $76.00 \pm 2.85$ & $74.85 \pm 2.51$ & $73.94 \pm 2.39$ & $73.16 \pm 2.21$ & $72.24 \pm 2.09$ \\
\hline TU/TS & $3.60 \pm 0.43$ & $3.29 \pm 0.32$ & $3.1 \pm 0.30$ & $2.98 \pm 0.28$ & $2.84 \pm 0.25$ & $2.73 \pm 0.22$ & $2.60 \pm 0.19$ \\
\hline$I . V^{c}$ & $113.7 \pm 0.44$ & $111.3 \pm 0.48$ & $111.0 \pm 0.37$ & $109.4 \pm 0.39$ & $108.4 \pm 0.35$ & $107.1 \pm 0.29$ & $105.8 \pm 0.21$ \\
\hline
\end{tabular}

${ }^{a}$ Total saturated fatty acids; ${ }^{b}$ total unsaturated fatty acids; ${ }^{c}$ iodine value $\left(\mathrm{g} 100 \mathrm{~g}^{-1}\right)$. Values are expressed as the means \pm SD of three independent assays.

and chemical composition of soybean fatty acids (Basyony et al., 1989; Mahrous, 2007). The autoxidation of the unsaturated fatty acids occurred in soybean oil with fatty acid structure C16:1, C18:1, C18:2 and C18:3 therefore the oxidation depended on the site of the unsaturation. The fatty acid linoleic $\mathrm{C} 18: 2$ is considered to be the one most affected by $\gamma$-radiation which decreased by over $2 \%$ followed by oleic C18:1, linolenic C18:3 and palmitoleic C16:1 with an irradiation dose of 7.5 kGy. The data presented in Table 1 illustrate that the iodine value of the crude oil extracted from healthy un-irradiated soybean seeds was $113.7 \mathrm{~g}$ $100 \mathrm{~g}^{-1}$, whereas the $\gamma$-irradiation with dose levels of $0.5,1,2,3,5$ and $7.5 \mathrm{kGy}$ decreased the iodine

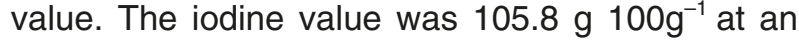
irradiation dose level of $7.5 \mathrm{kGy}$ as compared with the control. The decrease in iodine value upon irradiation could be attributed to some loss in the un-saturated fatty acids of soybean oil by radiation and the formation of peroxide compounds. These results are in agreement with the results obtained by several investigators (Shahin, 1993, Mohsen, 1996, Mahrous, 2007), who reported that a marked decrease in iodine value was noticed for irradiated soybean, sesame and cotton seed oil and the decrease was proportional to the irradiation doses. The obtained results confirm that irradiation accelerates the autoxidation process in unsaturated fatty acids in the presence of oxygen through the formation of free radicals and causes the breakdown and destruction of the antioxidants and change the chemical constituents of the lipid fraction (Hafez et al., 1985, Nawar, 1978).

\subsubsection{Peanut seeds}

The same trend for soybean could be observed in the case of the effect of different irradiation doses on the chemical composition of peanut fatty acids as shown in Table (2). The results show a slight decrease in the relative percentages of the unsaturated fatty acids C18:1 and C18:2 and slight increase in the percentages of the saturated ones C14:0, C16:0, C18:0, C20:0 C22:0 and C22:0 with increases in irradiation dosage. The present findings agree with those obtained by Chiou et al. (1991). The ratio between total unsaturated fatty acids and saturated ones (TU/TS) was 3.76 for control peanut oil seeds, while it gradually decreased in parallel with the irradiation doses as confirmed by the calculated iodine value. The unsaturated fatty acids of peanut oleic C18:1 and linoleic C18:2 comprised over $88 \%$ and affected by $\gamma$-radiation and reduced by $3 \%$ of the total fatty acid composition. $\gamma$ - radiation is known to cause the breakdown of the unsaturation site in the unsaturated fatty acid (Chiou et al., 1990). Our results revealed the presence of the short chain fatty acid caprilic C8:0 in irradiated peanut with doses from 0.5 to $7.5 \mathrm{kGy}$ with 0.53 to $0.99 \%$ respectively. On the other hand, the long chain saturated fatty acids arachidic $\mathrm{C} 20: 0$, behenic $\mathrm{C} 22: 0$ and lignoceric C24:0 were increased to reach their maximum levels with $7.5 \mathrm{kGy}$. These findings may be due to the inter conversion between fatty acids which occur under the irradiation treatment. The decrease in iodine values of peanut oil ranged from 95.24 to $88.44 \mathrm{~g}^{1} 100 \mathrm{~g}^{-1}$ oil from the control to $7.5 \mathrm{kGy}$ radiation doses respectively (Table 2 ). Other investigators also found decreases in the iodine values of gamma irradiated 
Table 2

Fatty acid composition of peanut irradiated with different doses of gamma rays

\begin{tabular}{|c|c|c|c|c|c|c|c|}
\hline \multirow{2}{*}{ Fatty Acids } & \multicolumn{7}{|c|}{ Irradiation dose (kGy) } \\
\hline & Control 0.0 & 0.5 & 1 & 2 & 3 & 5 & 7.5 \\
\hline Caprilic (8:0) & $0.34 \pm 0.01$ & $0.53 \pm 0.02$ & $0.89 \pm 0.05$ & $0.89 \pm 0.06$ & $0.79 \pm 0.04$ & $0.80 \pm 0.06$ & $0.99 \pm 0.07$ \\
\hline Myristic (14:0) & $0.40 \pm 0.03$ & $0.66 \pm 0.05$ & $0.76 \pm 0.06$ & $0.82 \pm 0.07$ & $0.90 \pm 0.08$ & $0.99 \pm 0.06$ & $1.08 \pm 0.09$ \\
\hline Palmitic (16:0) & $12.25 \pm 0.33$ & $12.49 \pm 0.41$ & $13.37 \pm 0.49$ & $13.57 \pm 0.51$ & $13.70 \pm 0.54$ & $13.68 \pm 0.57$ & $14.00 \pm 0.63$ \\
\hline Stearic (18:0) & $3.86 \pm 0.21$ & $4.40 \pm 0.26$ & $4.60 \pm 0.29$ & $4.75 \pm 0.34$ & $4.83 \pm 0.37$ & $4.93 \pm 0.40$ & $4.98 \pm 0.48$ \\
\hline Oleic (18:1) & $45.10 \pm 0.74$ & $43.30 \pm 0.61$ & $42.39 \pm 0.59$ & $42.43 \pm 0.61$ & $42.12 \pm 0.79$ & $41.92 \pm 0.67$ & $41.36 \pm 0.59$ \\
\hline Linoleic (18:2) & $31.50 \pm 0.55$ & $31.13 \pm 0.47$ & $30.23 \pm 0.44$ & $30.20 \pm 0.59$ & $30.12 \pm 0.38$ & $30.06 \pm 0.41$ & $29.72 \pm 0.29$ \\
\hline Arachidic (20:0) & $1.74 \pm 0.12$ & $2.26 \pm 0.14$ & $2.33 \pm 0.16$ & $2.18 \pm 0.20$ & $2.25 \pm 0.18$ & $2.33 \pm 0.13$ & $2.34 \pm 0.18$ \\
\hline Eicosanoic (20:1) & $2.40 \pm 0.09$ & $2.35 \pm 0.11$ & $2.14 \pm 0.13$ & $2.02 \pm 0.07$ & $1.96 \pm 0.05$ & $1.71 \pm 0.04$ & $1.78 \pm 0.07$ \\
\hline Behenic 22:0 & $1.85 \pm 0.11$ & $1.98 \pm 0.08$ & $2.35 \pm 0.12$ & $2.06 \pm 0.10$ & $2.14 \pm 0.14$ & $2.36 \pm 0.16$ & $2.39 \pm 0.18$ \\
\hline Lignoceric (24:0) & $0.91 \pm 0.06$ & $0.91 \pm 0.04$ & $0.95 \pm 0.07$ & $1.06 \pm 0.08$ & $1.20 \pm 0.11$ & $1.22 \pm 0.13$ & $1.35 \pm 0.15$ \\
\hline $\mathrm{TS}^{\mathrm{a}}$ & $21.00 \pm 0.33$ & $23.22 \pm 0.31$ & $25.25 \pm 0.29$ & $25.34 \pm 0.40$ & $25.78 \pm 0.42$ & $26.31 \pm 0.46$ & $27.14 \pm 0.49$ \\
\hline $\mathrm{TU}^{\mathrm{b}}$ & $79.00 \pm 2.36$ & $76.78 \pm 2.18$ & $74.75 \pm 2.28$ & $74.66 \pm 2.43$ & $74.20 \pm 2.25$ & $73.69 \pm 2.49$ & $72.86 \pm 2.37$ \\
\hline TU/TS & $3.76 \pm 0.32$ & $3.30 \pm 0.39$ & $2.96 \pm 0.24$ & $2.95 \pm 0.29$ & $2.88 \pm 0.26$ & $2.80 \pm 0.31$ & $2.68 \pm 0.30$ \\
\hline$I . V^{c}$ & $95.24 \pm 0.63$ & $93.01 \pm 0.45$ & $90.50 \pm 0.49$ & $90.40 \pm 0.53$ & $89.93 \pm 0.48$ & $89.49 \pm 0.51$ & $88.44 \pm 0.41$ \\
\hline
\end{tabular}

${ }^{a}$ Total saturated fatty acids; ${ }^{b}$ total unsaturated fatty acids; ${ }^{c}$ iodine value $\left(\mathrm{g} 100 \mathrm{~g}^{-1}\right)$. Values are expressed as the means \pm SD of three independent assays.

oil seeds (Lutfullah et al., 2003, Mahrous, 2007). The oxidation of the unsaturated site of fatty acids after irradiation will have an effect on oxidative conditions, especially antioxidant activity (Camargo et al., 2011; Afify et al., 2012b) and change the stability and the quality of oil as proven (Lalas et al., 2007, Mexis and Kontominas, 2009). Gamma radiation (8.0 kGy) increased the primary and secondary oxidation products of peanuts (Bhatti et al., 2010). Furthermore, the concentrations of the secondary grew faster. Volatile secondary compounds such as aldehydes, ketones and alcohols have had their concentration increased in peanuts, pistachio and cashew nuts submitted to gamma radiation with doses up to 7.0 kGy $[11,36]$, which indicate an increase in lipid oxidation (Camargo et al., 2011). Therefore the irradiation dose used for the peanut treatment should be selected very carefully without having any side effects on the chemical composition and physical characteristics of the peanut oil seeds (Bhatti et al., 2010).

\subsubsection{Sesame seeds}

The fatty acid profiles of total lipids of nonirradiated and irradiated sesame seeds at different doses are shown in Table 3. All sesame seed lipids

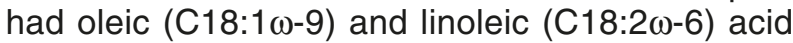

Table 3

Fatty acid composition of sesame irradiated with different doses of gamma rays

\begin{tabular}{lrrrrrrr}
\hline \multirow{2}{*}{ Fatty Acids } & \multicolumn{7}{c}{ Irradiation dose (kGy) } \\
\cline { 2 - 8 } & \multicolumn{1}{c}{ Control $\mathbf{0 . 0}$} & \multicolumn{1}{c}{$\mathbf{0 . 5}$} & \multicolumn{1}{c}{$\mathbf{1}$} & \multicolumn{1}{c}{$\mathbf{2}$} & \multicolumn{1}{c}{$\mathbf{3}$} & \multicolumn{1}{c}{$\mathbf{5}$} & \multicolumn{7}{c}{$\mathbf{7 . 5}$} \\
\hline Palmitic (16:0) & $9.93 \pm 0.54$ & $10.58 \pm 0.61$ & $10.87 \pm 0.68$ & $11.05 \pm 0.72$ & $11.37 \pm 0.78$ & $11.43 \pm 0.70$ & $11.56 \pm 0.68$ \\
Stearic (18:0) & $4.83 \pm 0.28$ & $5.45 \pm 0.37$ & $5.99 \pm 0.36$ & $6.60 \pm 0.39$ & $6.97 \pm 0.40$ & $7.30 \pm 0.41$ & $7.59 \pm 0.43$ \\
Oleic (18:1) & $44.57 \pm 0.59$ & $43.93 \pm 0.53$ & $43.97 \pm 0.47$ & $43.81 \pm 0.54$ & $43.16 \pm 0.38$ & $42.76 \pm 0.69$ & $42.44 \pm 0.66$ \\
Linoleic (18:2) & $40.66 \pm 0.55$ & $40.07 \pm 0.41$ & $39.17 \pm 0.49$ & $38.54 \pm 0.44$ & $38.51 \pm 0.52$ & $38.51 \pm 0.43$ & $38.41 \pm 0.47$ \\
TS $^{\mathrm{a}}$ & $14.77 \pm 0.33$ & $16.00 \pm 0.44$ & $16.86 \pm 0.35$ & $17.65 \pm 0.53$ & $18.34 \pm 0.65$ & $18.73 \pm 0.66$ & $19.15 \pm 0.59$ \\
TU $^{\mathrm{b}}$ & $85.23 \pm 1.02$ & $84.00 \pm 1.08$ & $83.14 \pm 0.78$ & $82.35 \pm 0.83$ & $81.66 \pm 0.94$ & $81.27 \pm 0.89$ & $80.85 \pm 0.96$ \\
TU/TS & $5.77 \pm 0.52$ & $5.25 \pm 0.48$ & $4.93 \pm 0.44$ & $4.66 \pm 0.39$ & $4.45 \pm 0.35$ & $4.33 \pm 0.30$ & $4.22 \pm 0.29$ \\
I.V & $108.77 \pm 0.87$ & $107.18 \pm 0.91$ & $105.65 \pm 0.78$ & $104.43 \pm 0.93$ & $103.81 \pm 0.84$ & $103.48 \pm 0.76$ & $103.03 \pm 0.81$ \\
\hline
\end{tabular}

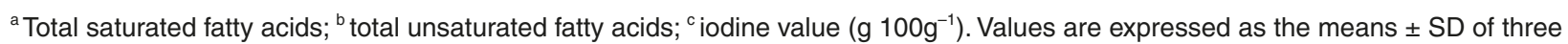
independent assays. 
as the most predominant among the unsaturated fatty acids, as well as palmitic (C16:0) and stearic (C18:0) acid as the most predominant among the saturated ones (Zoumpoulakis et al., 2012). The presented data show that an increase in the percentage of the saturated fatty acids C16:0 and C18:0 with a total increase of over $4 \%$ and decrease in the percentage of the unsaturated fatty acids C18:1 and C18:2 with a total decrease of over $5 \%$ with an irradiation dose of $7.5 \mathrm{kGy}$. These changes were noticed in the oil extracted from irradiated sesame seeds in comparison with the control sesame oil. The ratio between total unsaturated fatty acids and saturated ones (TU/ TS) was 5.77 for untreated oil, while it decreased gradually in parallel with the irradiation doses with iodine values ranging from 108 (control) to 103 (irradiated sesame at 7.5 KGy). The major changes in fatty acid composition were shown in the quantity of unsaturated fatty acids (18:1 and 18:2) which comprise over $85 \%$ in the control compared to more than $80 \%$ in the irradiated sesame with $7.5 \mathrm{kGy}$. Irradiation caused a significant gradual decrease in the unsaturated fatty acid content and a significant saturated fatty acid content increase as irradiation dose increased in sesame seeds (Zoumpoulakis et al., 2012). Also, a gradual decrease in iodine values was noticed in irradiated seeds and reached its maximum decrease at the highest dose of

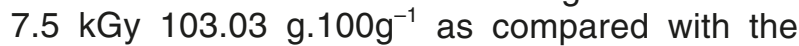
control. Although the irradiation dose used in our investigation is permitted to control insects and shelf life of oil seed with doses ranging from 1 to $5 \mathrm{kGy}$ in several countries including Egypt as reported by IAEA (1995) and FAOSTATE (1998). The application of these doses tn food causes a breakdown and disintegration of lipids, especially fatty acids in the site of the unsaturation such as oleic acid C18:1, linolenic acid C18:2 or linolenic C18:3 and produces different types of hydrocarbons which are considered artifacts in the oil seeds. Gamma irradiation with different levels of water deficit (moderate and severe water deficit) decreases the fatty acid content and unsaturation as verified by a significant reduction in oleic, linoleic, and linolenic acid proportions and the disappearance of palmitoleic acid (Yalcin et al., 2011) as revealed in our study. Therefore the next step in our investigation will be to study the new hydrocarbon produced from $\gamma$-radiation in the three oil seeds.

\subsection{Unsaponifiable matter composition}

It is well known that unsaponifiable matter contains several types of substances such as hydrocarbons besides sterols, pigments and vitamins and its very susceptible to being affected by $\gamma$-radiation because of its composition, especially the unsaturation sites. The hydrocarbons and sterols of the three oil seeds soybean, peanut and sesame, after irradiation with $\gamma$-ray doses of $0.5,1.0,2.0,3.0$,
5.0 and 7.5 kGy were studied and demonstrated. Tocopherol could not be detected under these conditions.

\subsubsection{Soybean seeds}

The data in Table 4 shows the unsaponifiable matter composition of irradiated soybean seeds according to the gamma ray doses. The presented data show that the non-irradiated soybean seeds contain 19:0, 20:0, 21:0, 22:0, $23: 0$ and $26: 0$ hydrocarbons which comprise $63 \%$ of the total unsaponifiable matter and represents $9.2,5.2,19.1,10.4,8.7$ and $7.6 \%$ respectively. The percentages of $22: 0,20: 0$ and 19:0 were decreased with irradiation depending on the dose. Some new unsaturated hydrocarbons 16:1, 16:2, 17:1 and 18:1 were detected in irradiated seeds with different doses and could not be detected in the control seeds. These results are in agreement with Hwang et al. (2007) who found that the hydrocarbons 17:1, 16:2, 17:2 and $16: 3$, induced from oleic and linoleic acids, were not detected in the lipids extracted from nonirradiated soybeans, while they were detected in fairly large amounts in the lipids from the samples irradiated at every level of tested doses. The detection levels of the hydrocarbons increased with dose. The hydrocarbons 15:0, 16:0 and 14:1, possibly radiation-induced from palmitic acid, and n-hexadecane (16:0) and 1-hexadecene $(16: 1)$, possibly from stearic acid, were detected in the non-irradiated samples and increased with irradiated dose. Sterols are quite important substances for human beings as they are the precursor of certain hormones, therefore the levels of sterol or sterol derived compound as affected by $\gamma$-radiation effect human health and play a major role in arteriosclerosis. The results in Table 4 show that the non-irradiated soybean seeds contained cholesterol, campesterol, stigmasterol and $\beta$-sitosterol and represents 1.2, 6.2, 0.3 and $2.3 \%$ respectively with total sterol of $10.2 \%$. The present investigation proves that $\gamma$-irradiation affected the sterol content of soybean seeds which decreased by increasing the $\gamma$-irradiation dose. Among the total sterols, stigmasterol was considered the major sterol to disappear starting with $3 \mathrm{kGy}$ irradiation doses. The ratio of total hydrocarbons to total sterols (TH/TSt) in irradiated soybean seeds were increased and reached its maximum with 7.5 kGy and represents 36.3 compared to the control 8.8. These results prove that the $\gamma$-irradiation of soybean seeds followed a general trend including increasing hydrocarbons and decreasing the sterol compounds. The prominent $\gamma$-radiation of soybean induced the unsaturated hydrocarbons 16:1, 16:2, 17:1 and 18:1 which could be derived from the decarboxylation and oxidation of stearic, oleic and may be from linolenic or eicosanoic acids, respectively. In addition to the induced unsaturated hydrocarbons, saturated hydrocarbons were increased by $\gamma$-irradiation and include 17:0 and 
Table 4

Unsaponifiable matter of soybean irradiated with different doses of gamma rays

\begin{tabular}{|c|c|c|c|c|c|c|c|}
\hline \multirow{2}{*}{ Components } & \multicolumn{7}{|c|}{ Irradiation dose (kGy) } \\
\hline & Control 0.0 & 0.5 & 1 & 2 & 3 & 5 & 7.5 \\
\hline $14: 0$ & $3.81 \pm 0.23$ & $2.24 \pm 0.18$ & $2.53 \pm 0.21$ & $2.07 \pm 0.19$ & $0.87 \pm 0.13$ & $0.13 \pm 0.01$ & $0.24 \pm 0.02$ \\
\hline $15: 0$ & $0.62 \pm 0.04$ & $0.11 \pm 0.01$ & $2.99 \pm 0.31$ & $4.09 \pm 0.37$ & $1.13 \pm 0.27$ & $0.19 \pm 0.03$ & $0.18 \pm 0.01$ \\
\hline $16: 0$ & $0.18 \pm 0.02$ & $0.22 \pm 0.01$ & $0.46 \pm 0.02$ & $0.24 \pm 0.01$ & $0.85 \pm 0.15$ & $0.98 \pm 0.19$ & $0.46 \pm 0.06$ \\
\hline $16: 1$ & 0.0 & $0.46 \pm 0.03$ & $0.51 \pm 0.02$ & $0.74 \pm 0.11$ & $0.39 \pm 0.10$ & $0.97 \pm 0.21$ & $1.18 \pm 0.23$ \\
\hline $16: 2$ & 0.0 & $0.22 \pm 0.02$ & $0.69 \pm 0.08$ & $0.72 \pm 0.12$ & $1.14 \pm 0.11$ & $1.70 \pm 0.16$ & $1.80 \pm 0.24$ \\
\hline $17: 0$ & $0.32 \pm 0.04$ & $1.21 \pm 0.14$ & $2.06 \pm 0.25$ & $1.27 \pm 0.09$ & $0.33 \pm 0.05$ & $0.43 \pm 0.06$ & $0.36 \pm 0.02$ \\
\hline $17: 1$ & 0.0 & $0.80 \pm 0.10$ & $0.84 \pm 0.11$ & $0.86 \pm 0.12$ & $1.23 \pm 0.08$ & $1.57 \pm 0.26$ & $2.15 \pm 0.30$ \\
\hline 18:0 & $0.75 \pm 0.04$ & $0.86 \pm 0.13$ & $3.33 \pm 0.22$ & $5.28 \pm 0.34$ & $5.27 \pm 0.38$ & $5.39 \pm 0.31$ & $2.96 \pm 0.13$ \\
\hline 18:1 & 0.0 & 0.0 & 0.0 & 0.0 & $0.26 \pm 0.02$ & $0.47 \pm 0.04$ & $0.53 \pm 0.03$ \\
\hline 19:0 & $8.16 \pm 0.39$ & $8.96 \pm 0.43$ & $7.74 \pm 0.44$ & $7.08 \pm 0.31$ & $5.35 \pm 0.23$ & $4.50 \pm 0.21$ & $6.81 \pm 0.20$ \\
\hline $20: 0$ & $10.24 \pm 0.51$ & $10.89 \pm 0.58$ & $9.38 \pm 0.25$ & $8.05 \pm 0.28$ & $5.13 \pm 0.21$ & $9.58 \pm 0.41$ & $4.60 \pm 0.19$ \\
\hline $21: 0$ & $6.23 \pm 0.37$ & $8.25 \pm 0.32$ & $7.09 \pm 0.40$ & $6.23 \pm 0.35$ & $5.10 \pm 0.24$ & $1.69 \pm 0.11$ & $0.87 \pm 0.13$ \\
\hline $22: 0$ & $20.2 \pm 0.63$ & $18.5 \pm 0.54$ & $20.6 \pm 0.59$ & $20.9 \pm 0.61$ & $20.4 \pm 0.72$ & $20.4 \pm 0.56$ & $19.4 \pm 0.57$ \\
\hline 23:0 & $10.43 \pm 0.29$ & $11.27 \pm 0.31$ & $5.32 \pm 0.22$ & $4.44 \pm 0.19$ & $4.33 \pm 0.20$ & $3.75 \pm 0.18$ & $3.98 \pm 0.19$ \\
\hline $24: 0$ & $2.70 \pm 0.08$ & $3.15 \pm 0.12$ & $3.47 \pm 0.15$ & $4.79 \pm 0.19$ & $5.67 \pm 0.14$ & $6.44 \pm 0.17$ & $8.11 \pm 0.27$ \\
\hline $25: 0$ & $3.77 \pm 0.15$ & $4.33 \pm 0.18$ & $5.76 \pm 0.21$ & $7.17 \pm 0.24$ & $9.50 \pm 0.39$ & $10.15 \pm 0.33$ & $11.63 \pm 0.34$ \\
\hline $26: 0$ & $8.66 \pm 0.44$ & $9.47 \pm 0.41$ & $10.43 \pm 0.48$ & $9.39 \pm 0.35$ & $9.30 \pm 0.39$ & $8.84 \pm 0.49$ & $9.59 \pm 0.29$ \\
\hline $27: 0$ & $2.19 \pm 0.11$ & $3.05 \pm 0.14$ & $4.11 \pm 0.18$ & $6.69 \pm 0.25$ & $9.79 \pm 0.27$ & $10.11 \pm 0.31$ & $11.70 \pm 0.43$ \\
\hline $28: 0$ & $2.40 \pm 0.23$ & $2.93 \pm 0.17$ & $3.41 \pm 0.21$ & $4.71 \pm 0.29$ & $6.16 \pm 0.22$ & $7.72 \pm 0.30$ & $8.97 \pm 0.20$ \\
\hline $29: 0$ & $1.51 \pm 0.03$ & $1.78 \pm 0.05$ & $1.68 \pm 0.08$ & $0.13 \pm 0.01$ & $1.71 \pm 0.14$ & $1.25 \pm 0.15$ & $0.11 \pm 0.01$ \\
\hline Squalene & $3.14 \pm 0.10$ & $0.24 \pm 0.04$ & $0.17 \pm 0.02$ & $0.12 \pm 0.01$ & $1.05 \pm 0.02$ & $0.32 \pm 0.03$ & $0.33 \pm 0.02$ \\
\hline $30: 0$ & $4.27 \pm 0.24$ & $5.17 \pm 0.29$ & $2.90 \pm 0.13$ & $0.78 \pm 0.17$ & $1.18 \pm 0.11$ & $0.36 \pm 0.04$ & $0.69 \pm 0.08$ \\
\hline $\mathrm{C}_{32}$ & $0.22 \pm 0.01$ & $0.40 \pm 0.03$ & $0.65 \pm 0.15$ & $1.47 \pm 0.19$ & $0.37 \pm 0.07$ & $0.24 \pm 0.01$ & $0.72 \pm 0.18$ \\
\hline Cholesterol & $1.234 \pm 0.14$ & $1.22 \pm 0.12$ & $0.50 \pm 0.03$ & $0.29 \pm 0.02$ & $0.92 \pm 0.04$ & $0.99 \pm 0.11$ & $0.92 \pm 0.10$ \\
\hline Campesterol & $6.22 \pm 0.43$ & $2.31 \pm 0.37$ & $1.48 \pm 0.19$ & $1.26 \pm 0.12$ & $0.63 \pm 0.08$ & $0.48 \pm 0.02$ & $0.42 \pm 0.01$ \\
\hline Stigmasterol & $0.36 \pm 0.02$ & $0.20 \pm 0.01$ & $0.17 \pm 0.01$ & $0.15 \pm 0.01$ & 0.0 & 0.0 & 0.0 \\
\hline$\beta$-sitosterol & $2.40 \pm 0.08$ & $1.80 \pm 0.07$ & $1.70 \pm 0.10$ & $1.53 \pm 0.13$ & $1.37 \pm 0.11$ & $1.41 \pm 0.09$ & $1.34 \pm 0.12$ \\
\hline${ }^{\mathrm{a}} \mathrm{TH}$ & $89.79 \pm 0.55$ & $94.47 \pm 0.64$ & $96.14 \pm 0.72$ & $96.77 \pm 0.78$ & $97.08 \pm 0.62$ & $97.12 \pm 0.71$ & $97.32 \pm 0.83$ \\
\hline${ }^{\mathrm{b}} \mathrm{TSt}$ & $10.21 \pm 0.25$ & $5.53 \pm 0.14$ & $3.86 \pm 0.16$ & $3.23 \pm 0.18$ & $2.92 \pm 0.21$ & $2.88 \pm 0.09$ & $2.68 \pm 0.13$ \\
\hline $\mathrm{TH} / \mathrm{TS}$ & $8.8 \pm 0.28$ & $17.1 \pm 0.23$ & $26.2 \pm 0.31$ & $29.9 \pm 0.36$ & $33.3 \pm 0.41$ & $33.8 \pm 0.48$ & $36.3 \pm 0.52$ \\
\hline
\end{tabular}

${ }^{a}$ Total hydrocarbons; ${ }^{b}$ total sterols. Values are expressed as the means \pm SD of three independent assays.

18:0 which could be derived from stearic and oleic, respectively, as shown in Tables 4 and 5.

\subsubsection{Peanut seeds}

The present results in Table 6 show the unsaponifiable matter composition of irradiated peanut seeds with major hydrocarbons of 20:0, 22:0, 24:0, 26:0, 28:0 and 29:0 hydrocarbons, which represents $75.5 \%$ of the total unsaponifiable matter (Park and Hwang, 1999). The relative percentage of these hydrocarbons represents $11.3,25.2,10.6$, $12.3,8.8$ and $7.1 \%$ respectively. No unsaturated hydrocarbons were detected in the oil extracted from non-irradiated peanuts but saturated hydrocarbons only were detected as shown in Table 5 (Park and Hwang, 1999). On the other hand, the induced unsaturated hydrocarbons; 16:1, 16:2, 17:1, 16:3, $17: 2$ and $18: 1$ could be detected only in the irradiated peanut seeds starting from the low level of irradiation dose of $0.5 \mathrm{kGy}$ to the maximum irradiation dose of $7.5 \mathrm{kGy}$ as shown in Table 7.

The relative percentages of the induced unsaturated hydrocarbons were dose dependent and as a general trend, were increased by increasing irradiation dose. 
Table 5

Hydrocarbons induced in irradiated soybean seeds

\begin{tabular}{lccccccc}
\hline \multirow{2}{*}{$\begin{array}{c}\text { Parent fatty } \\
\text { acid }\end{array}$} & $\begin{array}{c}\text { Hydrocarbons } \\
\%\end{array}$ & $\mathbf{0 . 5}$ & $\mathbf{1 . 0}$ & $\mathbf{2 . 0}$ & $\mathbf{3 . 0}$ & $\mathbf{5 . 0}$ & $\mathbf{7 . 5}$ \\
\cline { 3 - 8 } & $\mathrm{C}_{16: 1}$ & $0.46 \pm 0.03$ & $0.51 \pm 0.02$ & $0.74 \pm 0.11$ & $0.39 \pm 0.10$ & $0.97 \pm 0.21$ & $1.18 \pm 0.23$ \\
Stearic acid & $\mathrm{C}_{16: 2}$ & $0.22 \pm 0.02$ & $0.69 \pm 0.08$ & $0.72 \pm 0.12$ & $1.14 \pm 0.11$ & $1.70 \pm 0.16$ & $1.80 \pm 0.24$ \\
Oleic acid & $\mathrm{C}_{17: 1}$ & $0.80 \pm 0.10$ & $0.84 \pm 0.11$ & $0.86 \pm 0.12$ & $1.23 \pm 0.08$ & $1.57 \pm 0.26$ & $2.15 \pm 0.30$ \\
& $\mathrm{C}_{18: 1}$ & 0.00 & 0.00 & 0.00 & $0.26 \pm 0.02$ & $0.47 \pm 0.04$ & $0.53 \pm 0.03$ \\
Linoleic acid or & & & & & & & \\
Eicosanoic acid & & & & & & & \\
\hline
\end{tabular}

Values are expressed as the means \pm SD of three independent assays.

Table 6

Unsaponifiable matter of peanut irradiated with different doses of Gamma rays

\begin{tabular}{|c|c|c|c|c|c|c|c|}
\hline \multirow{2}{*}{ Components } & \multicolumn{7}{|c|}{ Irradiation dose (kGy) } \\
\hline & Control 0.0 & 0.5 & 1 & 2 & 3 & 5 & 7.5 \\
\hline $14: 0$ & $0.09 \pm 0.01$ & $0.08 \pm 0.01$ & $0.02 \pm 0.01$ & $0.12 \pm 0.02$ & $0.61 \pm 0.05$ & $0.35 \pm 0.03$ & $0.98 \pm 0.06$ \\
\hline $15: 0$ & $0.14 \pm 0.02$ & $0.32 \pm 0.04$ & $0.53 \pm 0.08$ & $0.71 \pm 0.05$ & $1.40 \pm 0.12$ & $0.25 \pm 0.02$ & $0.21 \pm 0.01$ \\
\hline $16: 0$ & $0.26 \pm 0.03$ & $0.32 \pm 0.02$ & $1.27 \pm 0.07$ & $0.15 \pm 0.01$ & $1.88 \pm 0.05$ & $1.85 \pm 0.06$ & $1.86 \pm 0.08$ \\
\hline 16:1 & 0.0 & $0.15 \pm 0.02$ & $0.33 \pm 0.03$ & $0.51 \pm 0.04$ & $0.77 \pm 0.07$ & $0.80 \pm 0.05$ & $1.04 \pm 0.10$ \\
\hline $16: 2$ & 0.0 & $0.13 \pm 0.01$ & $0.35 \pm 0.02$ & $0.40 \pm 0.03$ & $0.43 \pm 0.05$ & $0.49 \pm 0.06$ & $0.53 \pm 0.04$ \\
\hline $16: 3$ & 0.0 & $0.22 \pm 0.02$ & $0.75 \pm 0.04$ & $0.79 \pm 0.06$ & $0.81 \pm 0.07$ & $0.92 \pm 0.05$ & $0.95 \pm 0.11$ \\
\hline $17: 0$ & 0.0 & $2.02 \pm 0.12$ & $2.03 \pm 0.14$ & $2.21 \pm 0.11$ & $2.22 \pm 0.19$ & $2.13 \pm 0.17$ & $2.31 \pm 0.15$ \\
\hline $17: 1$ & 0.0 & $0.37 \pm 0.13$ & $0.40 \pm 0.16$ & $0.55 \pm 0.18$ & $0.96 \pm 0.12$ & $1.95 \pm 0.22$ & $2.59 \pm 0.24$ \\
\hline $17: 2$ & 0.0 & $0.16 \pm 0.02$ & $0.20 \pm 0.01$ & $0.26 \pm 0.02$ & $0.29 \pm 0.03$ & $0.44 \pm 0.03$ & $0.72 \pm 0.05$ \\
\hline 18:0 & $0.30 \pm 0.02$ & $0.75 \pm 0.06$ & $0.22 \pm 0.02$ & $0.12 \pm 0.01$ & $2.92 \pm 0.04$ & $4.96 \pm 0.17$ & $6.02 \pm 0.19$ \\
\hline 18:1 & 0.0 & 0.0 & $0.14 \pm 0.01$ & $0.26 \pm 0.02$ & $0.70 \pm 0.03$ & $0.81 \pm 0.04$ & $1.06 \pm 0.02$ \\
\hline 19:0 & $2.56 \pm 0.14$ & $0.98 \pm 0.04$ & $1.43 \pm 0.08$ & $0.40 \pm 0.03$ & $0.50 \pm 0.04$ & $0.66 \pm 0.07$ & $1.43 \pm 0.10$ \\
\hline $20: 0$ & $11.39 \pm 0.29$ & $10.89 \pm 0.15$ & $9.74 \pm 0.13$ & $8.04 \pm 0.19$ & $7.26 \pm 0.22$ & $5.78 \pm 0.16$ & $5.58 \pm 0.24$ \\
\hline $21: 0$ & $2.07 \pm 0.11$ & $0.96 \pm 0.15$ & $1.26 \pm 0.18$ & $0.42 \pm 0.07$ & $1.36 \pm 0.13$ & $3.98 \pm 0.11$ & $4.57 \pm 0.19$ \\
\hline $22: 0$ & $25.2 \pm 0.57$ & $21.6 \pm 0.66$ & $20.6 \pm 0.71$ & $19.9 \pm 0.62$ & $18.9 \pm 0.55$ & $14.3 \pm 0.48$ & $12.6 \pm 0.32$ \\
\hline $23: 0$ & 0.0 & 0.0 & 0.0 & 0.0 & 0.0 & $5.39 \pm 0.28$ & $6.16 \pm 0.21$ \\
\hline $24: 0$ & $10.7 \pm 0.26$ & $13.9 \pm 0.19$ & $16.7 \pm 0.25$ & $18.8 \pm 0.18$ & $20.8 \pm 0.33$ & $17.6 \pm 0.23$ & $15.0 \pm 0.17$ \\
\hline $25: 0$ & $5.36 \pm 0.18$ & $6.35 \pm 0.21$ & $6.76 \pm 0.34$ & $6.24 \pm 0.38$ & $6.14 \pm 0.29$ & $5.72 \pm 0.40$ & $5.62 \pm 0.41$ \\
\hline $26: 0$ & $12.40 \pm 0.45$ & $8.73 \pm 0.36$ & $8.38 \pm 0.49$ & $8.55 \pm 0.27$ & $7.65 \pm 0.43$ & $7.82 \pm 0.34$ & $7.53 \pm 0.31$ \\
\hline $27: 0$ & $6.71 \pm 0.26$ & $7.80 \pm 0.20$ & $7.86 \pm 0.29$ & $10.6 \pm 0.31$ & $10.2 \pm 0.32$ & $9.24 \pm 0.23$ & $8.96 \pm 0.46$ \\
\hline $28: 0$ & $8.81 \pm 0.19$ & $8.66 \pm 0.21$ & $8.24 \pm 0.26$ & $7.03 \pm 0.34$ & $5.13 \pm 0.25$ & $5.12 \pm 0.18$ & $5.39 \pm 0.22$ \\
\hline 29:0 & $7.17 \pm 0.12$ & $8.46 \pm 0.19$ & $3.39 \pm 0.17$ & $6.60 \pm 0.27$ & $5.20 \pm 0.20$ & $3.67 \pm 0.18$ & $2.42 \pm 0.11$ \\
\hline Squalene & $3.05 \pm 0.13$ & $3.74 \pm 0.26$ & $3.53 \pm 0.30$ & $3.42 \pm 0.33$ & $2.13 \pm 0.16$ & $4.19 \pm 0.23$ & $4.28 \pm 0.28$ \\
\hline $30: 0$ & $0.66 \pm 0.04$ & $1.22 \pm 0.11$ & $1.80 \pm 0.14$ & $2.29 \pm 0.18$ & 0.0 & 0.0 & 0.0 \\
\hline $32: 0$ & $0.37 \pm 0.03$ & $0.24 \pm 0.01$ & $0.17 \pm 0.1$ & $0.26 \pm 0.02$ & $0.20 \pm 0.01$ & $0.30 \pm 0.03$ & $0.66 \pm 0.12$ \\
\hline Cholesterol & $0.15 \pm 0.02$ & 0.0 & 0.0 & 0.0 & 0.0 & 0.0 & 0.0 \\
\hline Campesterol & $0.49 \pm 0.03$ & $0.35 \pm 0.05$ & $0.31 \pm 0.03$ & $0.18 \pm 0.02$ & $0.19 \pm 0.01$ & $0.13 \pm 0.02$ & $0.09 \pm 0.01$ \\
\hline Stigmasterol & $0.31 \pm 0.01$ & $0.15 \pm 0.01$ & $0.15 \pm 0.02$ & $0.15 \pm 0.01$ & $0.16 \pm 0.02$ & $0.19 \pm 0.03$ & $0.09 \pm 0.02$ \\
\hline$\beta$-sitosterol & $1.84 \pm 0.14$ & $1.47 \pm 0.11$ & $1.22 \pm 0.14$ & $0.95 \pm 0.21$ & $0.92 \pm 0.11$ & $0.80 \pm 0.14$ & $0.78 \pm 0.12$ \\
\hline${ }^{\mathrm{a}} \mathrm{TH}$ & $97.21 \pm 0.72$ & $98.03 \pm 0.88$ & $98.33 \pm 0.81$ & $98.72 \pm 0.77$ & $98.74 \pm 0.89$ & $98.88 \pm 0.63$ & $99.04 \pm 0.76$ \\
\hline${ }^{\mathrm{b}} \mathrm{TSt}$ & $2.79 \pm 0.15$ & $1.97 \pm 0.21$ & $1.67 \pm 0.13$ & $1.28 \pm 0.19$ & $1.26 \pm 0.14$ & $1.12 \pm 0.05$ & $0.96 \pm 0.02$ \\
\hline $\mathrm{TH} / \mathrm{TS}$ & $34.8 \pm 0.29$ & $49.7 \pm 0.42$ & $60.0 \pm 0.47$ & $77.1 \pm 0.55$ & $78.2 \pm 0.60$ & $88.2 \pm 0.59$ & $103.5 \pm 0.92$ \\
\hline
\end{tabular}

${ }^{a}$ Total hydrocarbons; ${ }^{b}$ total sterols. Values are expressed as the means \pm SD of three independent assays. 
Table 7

Hydrocarbons induced in irradiated peanut seeds

\begin{tabular}{|c|c|c|c|c|c|c|c|}
\hline \multirow{2}{*}{$\begin{array}{l}\text { Parent fatty } \\
\text { acid }\end{array}$} & \multirow{2}{*}{$\begin{array}{c}\text { Hydrocarbons } \\
\%\end{array}$} & \multicolumn{6}{|c|}{ Irradiation dose (kGy) } \\
\hline & & 0.5 & 1.0 & 2.0 & 3.0 & 5.0 & 7.5 \\
\hline Stearic acid & $C_{16: 1}$ & $0.15 \pm 0.02$ & $0.33 \pm 0.03$ & $0.51 \pm 0.04$ & $0.77 \pm 0.07$ & $0.80 \pm 0.05$ & $1.04 \pm 0.10$ \\
\hline \multirow[t]{2}{*}{ Oleic acid } & $\mathrm{C}_{16: 2}$ & $0.13 \pm 0.01$ & $0.35 \pm 0.02$ & $0.40 \pm 0.03$ & $0.43 \pm 0.05$ & $0.49 \pm 0.06$ & $0.53 \pm 0.04$ \\
\hline & $C_{17: 1}$ & $0.37 \pm 0.13$ & $0.40 \pm 0.16$ & $0.55 \pm 0.18$ & $0.96 \pm 0.12$ & $1.95 \pm 0.22$ & $2.59 \pm 0.24$ \\
\hline Linoleic acid or & $C_{16: 3}$ & $0.22 \pm 0.02$ & $0.75 \pm 0.04$ & $0.79 \pm 0.06$ & $0.81 \pm 0.07$ & $0.92 \pm 0.05$ & $0.95 \pm 0.11$ \\
\hline \multirow[t]{2}{*}{ Eicosanoic acid } & $C_{17: 2}$ & $0.16 \pm 0.02$ & $0.20 \pm 0.01$ & $0.26 \pm 0.02$ & $0.29 \pm 0.03$ & $0.44 \pm 0.03$ & $0.72 \pm 0.05$ \\
\hline & $C_{18: 1}$ & 0.0 & $0.14 \pm 0.01$ & $0.26 \pm 0.02$ & $0.70 \pm 0.03$ & $0.81 \pm 0.04$ & $1.06 \pm 0.02$ \\
\hline
\end{tabular}

Values are expressed as the means \pm SD of three independent assays.

Besides the induced unsaturated hydrocarbon, the saturated hydrocarbon with 17:0 could be detected in irradiated peanut seeds at a high percentage starting from the low level of irradiation dose of $0.5 \mathrm{kGy}$ and represents over $2 \%$ which could be used as a biomarker for the irradiated peanuts (Park and Hwang, 1999). It is important to note that the saturated hydrocarbon in the irradiated peanut seeds has no general trend, while 20:0, C22:0, 26:0, 28:0 and 29:0 were decreased; other hydrocarbons 18:0, 24:0, 27:0 were increased depending on the irradiation dose applied. Our results are in agreement with Ming Li et al., (2011) who stated that the hydrocarbons 1,7-C16:2 and 8-C17:1 did not exist in the unirradiated peanuts while they were apparently detected in the sample irradiated at the dose range of 0.5-8.0 kGy. Radiation dose had a significant impact on radiolysis products. A greater radiation dose results in a greater concentration of hydrocarbons. According to Nawar's research, 1,7-C16:2 and 8-C17:1 were produced by oleic acid (C18:1) in the carbonylation of $\alpha-C-C$ and $\beta-C-C$ bonds of the decomposition products, respectively. In addition, oleic acid in peanuts had a high level (42.42\%) of the total oil (Cui et al., 1997), which could be the reason for the relatively high concentrations of 1,7-C16:2 and 8-C17:1 in irradiated peanuts. In the range 0.5-8 kGy, 1,7-C16:2 and 8-C17:1 had a good linear relationship with the radiation dose. The radiation dose can be determined by the concentration of the hydrocarbons, according to this linear relationship and under certain conditions (Ming Li et al., 2011).

\subsubsection{Sesame seeds}

The data in Table 8 show the unsaponifiable matter composition of treated sesame seeds according to the gamma ray doses. The nonirradiated sesame seeds contained; 17:0, 20:0, $21: 0,23: 0,24: 0$ and 25:0 which comprise more than $44 \%$ of the total unsaponifiable matter, with relative percentages of $4.4,10.4,6.08,14.1,5.3$ and $4.2 \%$ respectively. The relative percentage of the hydrocarbons 17:0 and 20:0 were fluctuated according to the irradiation dose applied.

On other hand, the hydrocarbon 22:0 was increased in its percentage as a general trend to reach its induced maximum with 2 a kGy irradiation dose. The hydrocarbons C16:1, 16:2, 16:3, 17:1 and 18:1 could be detected in irradiated sesame depending on the dose as shown in Table 9. The non-irradiated sesame seeds contained sterol compounds; campesterol, stigmasterol and $\beta$-sitosterol with relative percentages of $14.9,4.4$ and $26.1 \%$, respectively (Table 8 ). Our results are in agreement with Choi and Hwang (1997) who reported that no unsaturated hydrocarbons were detected in the oil extracted from unirradiated sesame seeds. It has been reported that hydrocarbons 16:1, 16:2, 16:3, 17:1 and 17:2 were detected in un-irradiated oils from peanut, sunflower and extra-virgin olive oils and small amounts of 17 alkane and alkenes were naturally present in avocado-pear oil, which made quantitative analysis difficult. The major irradiation-induced unsaturated hydrocarbons 16:1, 16:2, 16:3, 17:1 were detected in the irradiated sesame at $1.0 \mathrm{kGy}$ or higher. The amount of these induced hydrocarbons increased almost linearly with irradiation dose. The percentage of total sterol (45.5\% control) was decreased gradually with the irradiation doses of $\gamma$-irradiation (9.3\% at $7.5 \mathrm{kGy})$. The $\gamma$ irradiation doses caused the disintegration of the sterol compounds which could be arranged as follows campesterol < $\beta$-sitosterol < stigmasterol. The results show that there are induced unsaturated hydrocarbons and degradation of the sterol compounds as a result of $\gamma$-irradiation. The induced hydrocarbons could be predicted from the effect of $\gamma$-irradiation on the major constituents of the fatty acids of sesame; oleic 18:1 and linoleic 18:2 which comprise 44.5 and $40.6 \%$ and may be from sterol compounds at $45.5 \%$. The detection of unsaturated hydrocarbon in irradiated sesame was previously proven (Choi and Hwang, 1997; Kamal-Eldin et al., 1992).

In conclusion, $\gamma$-irradiation caused alteration of the unsaturated and saturated fatty acid compositions of soybean, peanut, and sesame seeds, which showed an increase in the relative amounts of saturated fatty acids and a decrease 
Table 8

Unsaponifiable matter of sesame irradiated with different doses of gamma rays

\begin{tabular}{|c|c|c|c|c|c|c|c|}
\hline \multirow{2}{*}{ Components } & \multicolumn{7}{|c|}{ Irradiation dose (kGy) } \\
\hline & Control 0.0 & 0.5 & 1 & 2 & 3 & 5 & 7.5 \\
\hline $16: 0$ & $0.22 \pm 0.02$ & $0.35 \pm 0.03$ & $0.48 \pm 0.05$ & $0.15 \pm 0.02$ & $0.14 \pm 0.02$ & $2.03 \pm 0.09$ & $0.32 \pm 0.04$ \\
\hline $16: 1$ & 0.0 & $0.05 \pm 0.01$ & $0.06 \pm 0.01$ & $0.16 \pm 0.03$ & $0.18 \pm 0.03$ & $1.30 \pm 0.04$ & $1.75 \pm 0.11$ \\
\hline 16:2 & 0.0 & $0.13 \pm 0.02$ & $0.13 \pm 0.02$ & $0.14 \pm 0.01$ & $0.15 \pm 0.01$ & $0.23 \pm 0.03$ & $0.24 \pm 0.02$ \\
\hline $16: 3$ & 0.0 & 0.0 & 0.0 & 0.0 & 0.0 & $0.85 \pm 0.11$ & $0.87 \pm 0.14$ \\
\hline $17: 0$ & $4.49 \pm 0.18$ & $4.58 \pm 0.13$ & $5.38 \pm 0.24$ & $5.39 \pm 0.28$ & $5.18 \pm 0.29$ & $7.07 \pm 0.35$ & $1.30 \pm 0.19$ \\
\hline $17: 1$ & 0.0 & $0.35 \pm 0.02$ & $0.55 \pm 0.06$ & $0.81 \pm 0.09$ & $1.08 \pm 0.12$ & $2.08 \pm 0.28$ & $2.60 \pm 0.35$ \\
\hline 18:0 & $1.72 \pm 0.24$ & $2.37 \pm 0.31$ & $3.68 \pm 0.41$ & $3.68 \pm 0.39$ & $3.71 \pm 0.42$ & $3.99 \pm 0.38$ & $4.96 \pm 0.44$ \\
\hline $18: 1$ & 0.0 & 0.0 & $0.48 \pm 0.08$ & $0.61 \pm 0.11$ & $0.85 \pm 0.18$ & $0.93 \pm 0.17$ & $1.32 \pm 0.20$ \\
\hline 19:0 & $0.56 \pm 0.03$ & $0.81 \pm 0.07$ & $3.78 \pm 0.21$ & $3.68 \pm 0.18$ & $4.04 \pm 0.24$ & $0.61 \pm 0.05$ & $0.96 \pm 0.10$ \\
\hline $20: 0$ & $10.4 \pm 0.19$ & $11.8 \pm 0.31$ & $9.81 \pm 0.38$ & $13.1 \pm 0.42$ & $10.28 \pm 0.34$ & $10.08 \pm 0.29$ & $11.85 \pm 0.48$ \\
\hline $21: 0$ & $6.09 \pm 0.17$ & $4.00 \pm 0.09$ & $4.48 \pm 0.22$ & $5.00 \pm 0.25$ & $5.77 \pm 0.29$ & $5.50 \pm 0.31$ & $6.68 \pm 0.34$ \\
\hline $22: 0$ & $1.57 \pm 0.04$ & $7.21 \pm 0.43$ & $9.30 \pm 0.49$ & $11.9 \pm 0.50$ & $11.2 \pm 0.48$ & $10.2 \pm 0.37$ & $9.8 \pm 0.35$ \\
\hline 23:0 & $14.2 \pm 0.43$ & $12.2 \pm 0.49$ & $10.4 \pm 0.36$ & $10.2 \pm 0.28$ & $10.1 \pm 0.33$ & $11.8 \pm 0.44$ & $12.0 \pm 0.57$ \\
\hline $24: 0$ & $5.32 \pm 0.24$ & $6.50 \pm 0.37$ & $5.26 \pm 0.39$ & $6.79 \pm 0.42$ & $8.16 \pm 0.49$ & $9.26 \pm 0.23$ & $10.2 \pm 0.26$ \\
\hline $25: 0$ & $4.29 \pm 0.36$ & $5.85 \pm 0.41$ & $7.24 \pm 0.25$ & $8.21 \pm 0.28$ & $8.37 \pm 0.29$ & $7.48 \pm 0.38$ & $8.11 \pm 0.40$ \\
\hline $26: 0$ & $0.39 \pm 0.03$ & $6.81 \pm 0.19$ & $4.67 \pm 0.21$ & $4.89 \pm 0.26$ & $5.07 \pm 0.34$ & $6.19 \pm 0.41$ & $6.77 \pm 0.51$ \\
\hline $27: 0$ & $0.15 \pm 0.44$ & $5.81 \pm 0.48$ & $3.88 \pm 0.25$ & $3.33 \pm 0.18$ & $2.96 \pm 0.17$ & $3.50 \pm 0.27$ & $5.47 \pm 0.33$ \\
\hline $28: 0$ & $0.40 \pm 0.06$ & $3.1 \pm 0.14$ & $1.28 \pm 0.11$ & $2.40 \pm 0.15$ & $2.20 \pm 0.23$ & $3.22 \pm 0.26$ & $4.35 \pm 0.34$ \\
\hline 29:0 & $2.91 \pm 0.18$ & $1.68 \pm 0.11$ & $0.15 \pm 0.02$ & $1.23 \pm 0.07$ & $2.61 \pm 0.11$ & $2.01 \pm 0.14$ & $0.71 \pm 0.09$ \\
\hline Squalene & $0.57 \pm 0.04$ & $0.48 \pm 0.03$ & $0.27 \pm 0.03$ & $0.08 \pm 0.01$ & $0.90 \pm 0.05$ & $0.09 \pm 0.01$ & $0.05 \pm 0.01$ \\
\hline $30: 0$ & $0.30 \pm 0.02$ & $1.1 \pm 0.09$ & $0.10 \pm 0.01$ & $0.31 \pm 0.02$ & $0.89 \pm 0.08$ & 0.0 & 0.0 \\
\hline $32: 0$ & $0.93 \pm 0.10$ & $0.76 \pm 0.12$ & $0.37 \pm 0.04$ & $0.30 \pm 0.03$ & $0.59 \pm 0.04$ & $0.12 \pm 0.02$ & $0.18 \pm 0.03$ \\
\hline Campesterol & $15.0 \pm 0.49$ & $9.62 \pm 0.43$ & $6.38 \pm 0.27$ & $5.11 \pm 0.25$ & $4.92 \pm 0.26$ & $3.59 \pm 0.29$ & $2.55 \pm 0.18$ \\
\hline Stigmasterol & $4.40 \pm 0.28$ & $4.13 \pm 0.22$ & $6.52 \pm 0.31$ & $1.31 \pm 0.10$ & $2.15 \pm 0.28$ & $1.97 \pm 0.10$ & $1.47 \pm 0.15$ \\
\hline$\beta$-sitosterol & $26.13 \pm 0.52$ & $10.6 \pm 0.30$ & $10.0 \pm 0.17$ & $9.32 \pm 0.46$ & $7.97 \pm 0.33$ & $6.05 \pm 0.29$ & $5.42 \pm 0.34$ \\
\hline${ }^{\mathrm{a}} \mathrm{TH}$ & $54.48 \pm 0.78$ & $75.6 \pm 0.89$ & $77.1 \pm 0.91$ & $82.3 \pm 0.92$ & $84.9 \pm 0.90$ & $88.4 \pm 0.88$ & $90.6 \pm 0.98$ \\
\hline${ }^{\mathrm{b}} \mathrm{TSt}$ & $45.52 \pm 0.65$ & $24.4 \pm 0.51$ & $22.9 \pm 0.32$ & $17.7 \pm 0.41$ & $15.1 \pm 0.45$ & $11.6 \pm 0.49$ & $9.44 \pm 0.53$ \\
\hline $\mathrm{TH} / \mathrm{TS}$ & $1.19 \pm 0.11$ & $3.1 \pm 0.34$ & $3.36 \pm 0.26$ & $4.63 \pm 0.44$ & $5.63 \pm 0.39$ & $7.60 \pm 0.23$ & $9.59 \pm 0.45$ \\
\hline
\end{tabular}

${ }^{a}$ Total hydrocarbons; ${ }^{b}$ total sterols. Values are expressed as the means \pm SD of three independent assays.

Table 9

Hydrocarbons induced in irradiated sesame seeds

\begin{tabular}{|c|c|c|c|c|c|c|c|}
\hline \multirow{2}{*}{$\begin{array}{l}\text { Parent fatty } \\
\text { acid }\end{array}$} & \multirow{2}{*}{$\begin{array}{c}\text { Hydrocarbons } \\
\%\end{array}$} & \multicolumn{6}{|c|}{ Irradiation dose (kGy) } \\
\hline & & 0.5 & 1.0 & 2.0 & 3.0 & 5.0 & 7.5 \\
\hline Stearic acid & $C_{16: 1}$ & $0.05 \pm 0.01$ & $0.06 \pm 0.01$ & $0.16 \pm 0.03$ & $0.18 \pm 0.03$ & $1.30 \pm 0.04$ & $1.75 \pm 0.11$ \\
\hline \multirow[t]{2}{*}{ Oleic acid } & $C_{16: 2}$ & $0.13 \pm 0.02$ & $0.13 \pm 0.02$ & $0.14 \pm 0.01$ & $0.15 \pm 0.01$ & $0.23 \pm 0.03$ & $0.24 \pm 0.02$ \\
\hline & $C_{17: 1}$ & $0.35 \pm 0.02$ & $0.55 \pm 0.06$ & $0.81 \pm 0.09$ & $1.08 \pm 0.12$ & $2.08 \pm 0.28$ & $2.60 \pm 0.35$ \\
\hline Linoleic acid or & $C_{16: 3}$ & 0.0 & 0.0 & 0.0 & 0.0 & $0.85 \pm 0.11$ & $0.87 \pm 0.14$ \\
\hline Eicosanoic acid & $\mathrm{C}_{18: 1}$ & 0.0 & $0.48 \pm 0.08$ & $0.61 \pm 0.11$ & $0.85 \pm 0.18$ & $0.93 \pm 0.17$ & $1.32 \pm 0.20$ \\
\hline
\end{tabular}

Values are expressed as the means \pm SD of three independent assays. 
in the unsaturated fatty acids. The ratio between total unsaturated fatty acids and saturated ones (TU/TS) decreased gradually in parallel with the irradiation doses and confirmed with the results of iodine values. The iodine values decreased in the three oil seeds and the decrease was proportional to the irradiation doses. The detection of the induced saturated and unsaturated hydrocarbons was made only in the irradiated oil seeds. The relative percentages of the induced unsaturated hydrocarbons were dose dependent and as a general trend, increased by increasing the irradiation dose. The detection of the induced saturated and unsaturated hydrocarbon could be used as a biomarker index for irradiated food or for biological insect control. The induced hydrocarbons could be predicted from the effect of $\gamma$-irradiation on the major constituents of fatty acids or may be derived from the degradation of sterol compounds or from the disintegration of the high molecular weight components of the cell structure in the three oil seeds. Therefore irradiation dose should not exceed the permitted irradiation dose as recommended and lowering the dose should be taken into consideration in order to meet the requirements and lower the side effects resulting from its application to food consumption.

\section{ACKNOWLEDGMENTS}

The authors would like to thank the management of the Faculty of Agriculture and Cairo University for ongoing cooperation to support this research and that provided funds and facilities necessary to achieve the desired goals of this research.

\section{REFERENCES}

Afify AMR, Rashed MM, Ebtesam AM, El-Beltagi HS. 2011a. Effect of gamma radiation on protein profile, protein fraction and solubility of three oil seeds. Not. Bot. Hort. Agrobot. Cluj. 39, 90-98.

Afify AMR, El-Beltagi HS, Fayed SA, Shalaby EA. 2011b. Acaricidal activity of successive extracts from Syzygium cumini L. Skeels (Pomposia) against Tetranychus urticae Koch. Asian Pac. J. Trop. Biomed. 1, 359-364.

Afify AMR, El-Beltagi HS, Aly AA, El-Ansary AE. 2012a. Antioxidant enzyme activities and lipid peroxidation as biomarker compounds for potato tuber stored by gamma radiation. Asian Pac. J. Trop. Biomed. 2, S1548-S1555.

Afify AMR, El-Beltagi HS, Aly AA, El-Ansary AE. 2012b. Antioxidant enzyme activities and lipid peroxidation as biomarker for potato tuber stored by two essential oils Caraway and Clove and its main component Carvone and Eugenol. Asian Pac. J. Trop. Biomed. 2, S772-S780.

Ahmed FA, Ragaa OO, Khalil FA. 1986. Biochemical studies of the effect of growth regulator on safflower plant. Grasas Aceites 37, 68-71.

Alaoui JMA, Batist G, Lehnert S. 1992. Radiation-induced damage to DNA in drug- and radiation-resistant sublines of a human breast cancer cell lines. Radiat. Res. 129, 37-42.

Aly AA, El-Beltagi HES. 2010. Influence of ionizing irradiation on the antioxidant enzymes of Vicia faba $L$. Grasas Aceites 61, 288-294.

AOAC. 2000. Official Methods of Analysis of the Association of Official Analytical Chemists, $17^{\text {th }}$ edn (edited by W. Horwitz) Washington, DC.

Ashri A. 2007. Sesame (Sesamum indicum L.). In: R.J. Singh, Ed., Genetics Resources, Chromosome Engineering, and Crop Improvement, Vol.4, Oilseed Crops, p. 231289, CRC Press, Boca Raton, FL, USA.

Basyony AE, El-Refaei MI, Galal MS, Barakat MIE. 1989. Effect of gamma irradiation on seed-borne fungi and soybean seed components during storage. Agric. Res. Rev. 67, 619-628.

Bhatti IA, Ashraf S, Shahid M, Asi MR, Mehboob S. 2010. Quality index of oils extracted from gamma-irradiated peanuts (Arachis hypogaea L.) of the golden and bari varieties. Appl. Radiat. Isotopes. 68, 2197-2201.

Camargo AC, Canniatti-Brazaca SG, Mansi DN, Domingues MAC, Arthur V. 2011. Efeitos da radiação gama na cor, capacidade antioxidante e perfil de ácidos graxos em amendoim (Arachis hypogaea L.). Ciênc. Tecnol. Aliment. 31, 11-15.

Cetinkaya N, Ozyardımci B, Denli E, Ic E 2006. Radiation processing as a post harvest quarantine control for raisins, dried figs and apricots. Radiat. Phys. Chem. 75, 424-431.

Champagne JR, Nawar WW. 1969. The volatile components of irradiated beef and pork fats. J. Food Sci. 34, 335-339.

Charbaji T, Nabulsi I. 1999. Effect of low dosess of gamma irradiation on in vitro growth of grapevine. Plant Cell Tiss. Organ Cult. 57, 129-132.

Chiou RYY, Shyu SL, Tasi CL. 1990. Characterization of gamma irradiated peanut kernels stored one year under ambient and frozen conditions. J. Food Sci. 56, 1375-1377.

Chiou RYY, Tseng CY, Ho S. 1991. Characteristics of peanut kernels roasted under various atmospheric environments. J. Agric. Food Chem. 39, 1852-1856.

Cui K, Xiao G, Yao WR. 1997. Analysis of fatty acids composition of peanut food. Peanut Sci. Technol. 4, 17-18.

Dogbevi MK, Vachon C, Lacroix M, 1999. Physicochemical and microbiological changes in irradiated fresh pork loins. Meat Sci. 51, 349-354.

Choi CR, Hwang KT. 1997. Detection of hydrocarbons in irradiated and roasted sesame seeds. J. Am. Oil Chem. Soc. 74, 496-472.

Dubravcic MD, Nawar WW. 1968. Radiolysis of lipids. Mode of cleavage in simple triglycerides. J. Am. Oil Chem. Soc. 45, 656-660.

Dubravcic MF, Nawar WW. 1969. Effects of high-energy radiation on the lipids of fish. J. Agric. Food Chem. 17, 639-644.

El-Beltagi HS. 2001. Biochemical studies on some Egyptian plants and its relation with environment. M. Sc. Thesis, Biochemistry Department, Faculty of Agriculture, Cairo University.

El-Beltagi HES. 2011. Effect of roasting treatments on protein fraction profiles, some enzyme activities of Egyptian peanuts. Int. J. Food Sci. Nutr. 62, 453-456.

El-Beltagi HS, Kesba HH, Abdel-Alim Al, Al-Sayed AA. 2011a. Effect of root-knot nematode and two species of crown on antioxidant activity of grape leaves. Afr. J. Biotechnol. 10, 12202-12210. 
El-Beltagi HS, Ahmed OK, El-Desouky W. 2011b. Effect of low doses $\gamma$-irradiation on oxidative stress and secondary metabolites production of rosemary (Rosmarinus officinalis L.) callus culture. Radiat. Phys. Chem. 80, 968-976.

El-Beltagi HS, Farahat AA, Alsayed AA, Mahfoud NA. 2012. Response of antioxidant substances and enzymes activities as a defense mechanism against root-knot nematode infection. Not. Bot. Hort. Agrobot. Cluj. 40, 132-142.

Erickson DR, Pryde EH, Brekke OL, Mounts TL, Falb RA. 1980. Handbook of Soy Oil Processing and Utilization. American Soybean Association and the American Oil Chemist's Society. St. Louis, Missouri and Champaign, Illinois.

Ewing D, Jones SR. 1987. Superoxide removal and radiation protection in bacteria, Arch. Biochem. Biophys. 254, 53-62.

FAOSTATE Agriculture Data, Food and Agriculture Organization of the United Nations, Roma, Italy (http://apps. Fao.org) (1998).

Foyer $\mathrm{CH}$, Noctor G. 2002. Oxygen processing in photosynthesis: regulation and signaling. New Phytol. 146, 359-388.

Golge E, Ova G. 2008. The effects of food irradiation on quality of pine nut kernels. Radiat. Phys. Chem. 77, 365-369.

Gunckel JE, Sparrow AH. 1961. Ionizing radiations: Biochemical, Physiological and Morphological aspects of their effects of plants. Encyclopedia of Plant Physiology, Springer-Verlag, Berlin, 16, 555611.

Hafez YS, Mohamed AI, Singh G, Hewedy FM. 1985. Effect of gamma irradiation on protein and fatty acids of soybean. J. Food Sci. 50, 1271.

Hwang KT. 1999a. Hydrocarbons detected in irradiated pork, bacon and ham. Food Res. Inter. 32, 389-394.

Hwang KT. 1999b. Hydrocarbons detected in irradiated shell eggs during storage. J. Am. Oil Chem. Soc. 76, 1183-1187.

Hwang KT, Yoo JH, Kim CK, Uhm TB, Kim SB, Park HJ. 2001. Hydrocarbons detected in irradiated and heattreated eggs. Food Res. Inter. 43, 321-328.

Hwang KT, Kim JY, Park JN, Yang JS. 2007. Effects of roasting, powdering and storing irradiated soybeans on hydrocarbon detection for identifying post irradiation of soybeans. Food Chem. 102, 263-269.

IAEA, Food Irradiation Newsitter (supplement) 1995. 19, 1-35.

Jiang ST, Shao1 P, Pan LJ, Zhao YY. 2006. Molecular Distillation for recovering Tocopherol and Fatty Acid Methyl Esters from Rapeseed Oil. Deodoriser Distillate Biosystems Engineering 93, 383-391.

Kamal-Eldin A, Yousif G, Appelqvist LA. 1992. Seed lipids of Sesamum indicum and related wild species in Sudan. The sterols. J. Sci. Food Agric. 56, $327-$ 334

Katsaras J, Stinson RH, Kendal EJ, McKersie BD. 1986. Structural simulation of free radical damage in amodelmembrane system: a smallangle X-ray diffraction study. Biochim. Biophys. Acta. 861, 243250.

Lalas S, Gortzi O, Tsaknis J, Sflomos K. 2007. Irradiation Effect on Oxidative Condition and Tocopherol Content of Vegetable Oils. Inter. J. Mol. Sci. 8, 533-540.

Lawrie RA. 1974. "Meat Science": $2^{\text {nd }}$ ed. Pergmon Press Ltd. Ozford, England.

Lesgards G, Raffi J, Pouliquen I, Chaouch AA, Giamarchi $\mathrm{P}$, Prost M. 1993. Use of radiation-induced alkanes and alkenes to detect irradiated food containing lipids. J. Am. Oil Chem. Soc. 70, 179-185.

Lee YS, Oh SH, Lee JW, Kim JH, Kim DS, Byun MW. 2003. Effects of gamma irradiation on physicochemical and textural properties of starches. Food Sci. Biotechnol. 12, 508-512.

Lutfullah G, Zeb A, Ahmed T, Atta S, Bangash FK. 2003. Changes in the quality of sunflower and soybean oils induced by high doses of gamma radiations. J. Chem. Soc. Pak. 25, 69-76.

Mahrous SR. 2007. Chemical Properties of Aspergillus flavus-Infected Soybean Seeds Exposed to $\gamma$-Irradiation during Storage. Int. J. Agri. Biol. 9, 231238.

Messina MJ. 1997. Soybean foods: their role in disease prevention and treatment. In Soybean: Chemistry, Technology, and Utilization. Chapman and Hall: New York, USA, pp. 442-447.

Mexis SF, Kontominas MG. 2009. Effect of gamma irradiation on the physic-chemical and sensory properties of raw shelled peanuts (Arachis hypogaea L.) and pistachio nuts (Pistacia vera L.). J. Sci. Food Agric. 89, 867-875.

Ming Li W, Li A, Ming Ha Y, Wang F, Li Zhang Y. 2011. Detection of gamma-irradiated peanuts by ESR spectroscopy and GC analysis of hydrocarbons. Radiat. Phys. Chem. 80, 501-504.

Mohamed HMA, Awatif II. 1998. The use of sesame oil unsaponifiable matter as a natural antioxidant. Food Chem. 62, 269-276.

Mohsen GIM. 1996. Effect of gamma radiation on microbial contamination and poisoning substances in some oil seeds and their products. Ph. D. Thesis, Department of Food Science and Technology, Faculty of Agriculture, Al-Azhar University, Cairo, Egypt.

Nawar WW. 1978. Reaction mechanisms in the radiolysis of fats: A review. J Agric Food Chem. 26, 21-25.

Nelson RG, Valeria N, Carlos AG. 2000. Chemical composition of some wild peanut species (Arachis L.) seeds. J. Agric. Food Chem. 48, 806-809.

Olsson M 1995. Alterations in lipid composition, lipid peroxidation and anti-oxidative protection during senescence in drought stressed plants and nondrought stressed plants of Pisum sativum. Plant Physiol. Biochem. 33, 547-553.

Oyinlola A, Ojo A, Adekoya LO. 2004. Development of a laboratory model screw press for peanut oil expression. J. Food Eng. 64, 221-227.

Park JY, Hwang KT. 1999. Hydrocarbons as markers for identifying post- irradiated peanuts. J. Am. Oil Chem Soc. 76, 125-129.

Patterson HBW. 1989. Handling and storage of oilseeds, oils, fats and meal. Elsevier App Sci NewYork.

Repine JE, Pfenninge DW, Talmage DW, Berger EM, Pettijohn DE. 1981. Dimethyl sulfoxide prevents DNA nicking mediated by ionizing radiation or iron/ hydrogen peroxide-generated hydroxyl radical. Proceedings of the National Academy of Sciences. USA 78, 1001-1003.

Shahin Azza AM 1993. Control of fungus diseases during storage of certain economic crops using gamma radiation. Ph. D Thesis, Faculty of Agriculture Cairo University, Cairo, Egypt.

Sokolov AA 1965. Physico-chemical and biochemical basis of meat products technology. Food Industry pub. Moscow. (C. F. chem. Abs. 65, 11240c).

Spiegelberg A, Schulzki G, Helle N, Bogl KW, Schreiber GA. 1994. Methods for routine control of irradiated food: optimization of a method for detection of 
radiation-induced hydrocarbons and its application to various foods. Radiat. Phys. Chem. 43, 433-444.

Steel LK, Hughes HN, Walden TL. 1988. Quantitative function and biochemical alterations in the peritoneal cells of mice exposed to whole-body gammairradiation. Int. J. Radiat. Biol. 53, 943-964.

Vogel Al 1975. A textbook of practical organic chemistry 3rd Ed., Longman, Group Limited London.

Voisine R, Vezina LP, Willemont C. 1991. Induction of senescence-like deterioration of micro small membranes from cauliflower by free radicals generated during gamma irradiation. Plant Physiol. 97, 545-550.

von Sonntag C. 1987. The Chemical Basis of Radiation Biology, Taylor and Francis, London.

Wills ED. 1980. Studies of lipid peroxide formation in irradiated synthetic diets and the effects of storage after irradiation. Int. J. Radiat. Biol. Relat. Stud. Phys. Chem. Med. 37, 383-401.

Wise RR, Naylor AW. 1987. Chilling-enhanced photooxidation. Evidence for the role of singlet oxygen and superoxide in the breakdown of pigments and endogenous antioxidants. Plant Physiol. 83, 278-282.

Xienia U, Foote GC, Van S, Devreotes PN, Alexander S, Alexander H. 2000. Differential developmental expression and cell type specificity of dictystelium catalases and their response to oxidative stress and UV light. Biochem. Biophys. Acta 149, 295-310.

Yalcin H, Ozturk I, Tulukcu E, Sagdic O. 2011. Effect of $\gamma$-irradiation on bioactivity, fatty acid compositions and volatile compounds of clary sage seed (Salvia sclarea L.). J. Food Sci. 76, 1056-1061.

Yook HS, Lee YS, Lee JW, Oh SH, Kim JH, Kim DS, Byun MW. 2004. Textural and sensory characteristics of gamma irradiated porridges. J. Korean Soc. Food Sci. Nutr. 33, 427-432.

Zoumpoulakis $\mathrm{P}$, Sinanoglou VJ, Batrinou A, Strati IF, Miniadis-Meimaroglou S, Sflomos K. 2012. A combined methodology to detect $\gamma$-irradiated white sesame seeds and evaluate the effects on fat content, physicochemical properties and protein allergenicity. Food Chem. 131, 713-721. 